\title{
Assessment of Water Handling Practices among Rural Communities of Dire Dawa Administrative Council, Dire Dawa, Ethiopia
}

\author{
Desalegn Amenu ${ }^{1^{\star}}$, Sissay Menkir ${ }^{2}$ and Tesfaye Gobena ${ }^{3}$ \\ ${ }^{1}$ College of Natural and Computation Science, Wollega University,Post Box No: 395, Nekemte, Ethiopia \\ ${ }^{2}$ Department of Biology, Haramaya University, Post Box No: 337, Dire Dawa, Ethiopia \\ ${ }^{3}$ College of Health Sciences, Haramaya University, Post Box No: 337, Dire Dawa, Ethiopia
}

\begin{abstract}
The aim of this study was to assess the impact of knowledge and hygienic practices of the community on bacteriological quality of drinking water at the source and point of use. A community based cross-sectional study was conducted using interviewer administered questionnaire, inspection check list to observe the condition of water sources, and bacteriological water quality examination of sources and household containers. The study was conducted during February-May 2011 in rural Communities of Dire Dawa Administrative Council. Three hundred eighty four households were selected using systematic random sampling method to assess the knowledge and hygienic practices of the community and gathered by health extension worker under strict supervision of principal investigator and supervisors. Bacteriological examination of six water sources systematically selected household containers was carried out by using Oxfam DelAgua water testing kit. Almost all of the water sources were subjected to contamination of faecal coliform with high sanitary risk score. There is a significant variation between the bacteriological analysis of source water and household drinking water samples. Educational status was the only variables which was significant after adjustment of other socio demographic, Knowledge and practices variables. However other variables like: types of household containers, washing of containers before transferring, methods of water withdrawal, duration of stored water and cover of container during transportation and storage were significant in bivariate analysis but not in multivariate analysis. This may be due to confounding effects of different variables. Protected springs with high sanitary risk score were highly subjected to bacteriological contamination and its load of feacal coliform almost tripled at household level, because of poor household management.
\end{abstract}

Article Information Article History:

Received : 07-04-2013

Revised : 20-06-2013

Accepted : 24-06-2013

\section{Keywords:}

Knowledge

Dire Dawa

Water

Practice

Faecal coliform

Bacteriological contamination

${ }^{*}$ Corresponding Author:

Desalegn Amenu

E-mail:

desalegnsore@gmail.com

\section{INTRODUCTION}

Water is the essence of life and safe drinking water is a basic human right essential to all, and for sustainable development. It is known that water is our most precious resource, vital to our economy, our daily lives and to the health of our environment. Water and sanitation inadequacies hinder economic and social development, constitute a major impediment to poverty alleviation and inevitably lead to environmental degradation (WHO, 2004). A community ravaged by diarrheal diseases, dracunculiasis or schistosomiasis cannot look beyond its immediate problems towards social and economic welfare. Safe water is the door way to health and health is the pre-requisite for progress, social equity and human dignity (WHO, 2004).
Access to safe water alone does not reduce diarrheal diseases significantly. Even if the source is safe water become faecally contaminated during collection, transportation, storage and drawing in the home. Inadequate hygiene practices must be targeted as well when implementing water and sanitation projects, to decrease morbidity and mortality especially in rural area. Along with building or improving water points therefore we should provide hygiene education for all user groups. Hygiene Promoters inform community members about the correct use and storage of water, the need for safe sanitation facilities, personal and environmental hygiene and diarrhea transmission 
Desalegn Amenu et al.,

and management, aiming at sustainable behavior change (Teferi Abegaz, 2007).

Protection of water supply from contamination is the first line of defense against disease. Because of the essential role water plays in supporting human life, it has if contaminated, great potential for transmitting a wide variety of disease and illnesses. Source protection almost invariably is the best method of ensuring safe drinking water. However, failure to provide adequate protection, poor site selection, and unhygienic practices of the consumers and deterioration of construction materials may contribute the contamination of water sources and resulting water borne diseases (Teferi Abegaz, 2007).

In Ethiopia, water supply and sanitation situation is inadequate. Most of the populations in urban and rural areas do not have access to safe and adequate water supplies and sanitation facilities. Regarding food, water and personal hygiene, only few households show sufficient understanding of environmental sanitation or hygienic practices. As a result, three-fourths of the health problems in Ethiopia are due to communicable diseases attributable to unsafe/inadequate water supply, and unhygienic/ unsanitary waste management, particularly excreta (UN-WATER/WWAP- National Water Development Report for Ethiopia, 2004).

Diarrhoeal diseases caused by improper management of water and sanitation are among the major causes of infant and child morbidity and mortality. Water and sanitation programs have a direct bearing on the prevalence of diarrhoeal diseases in the population. Water and sanitation projects, which are properly designed and implemented, have the potential of reducing diarrhoea-caused deaths by 55 percent. The combination of safe water supply, sanitation facilities and hygienic practices has demonstrated a potential in contributing to a remarkable reduction in mortality (UN-WATER/WWAP- National Water Development Report for Ethiopia, 2004).

In Ethiopia over $60 \%$ of the communicable diseases is due to poor environmental health conditions arising from unsafe and inadequate water supply and poor hygienic and sanitation practices. About $80 \%$ of the rural and $20 \%$ of urban population have no access to safe water; which is the least among the continent. Three-fourth of the health problems of children in the country are communicable diseases arising from the environment, especially water and sanitation $(\mathrm{MoH}$, 2007).
Sci. technol. arts Res. J., April-June 2013, 2(2): 75-82

Although safe water supply services are available in most places, the national as well as the regional information on the water quality status and the household management of local water sources is not readily available. This research tries to identify feacal coliform loads of protected springs and household drinking water containers and the main contributing factor towards the contamination of drinking water and variation of quality at the source and household level. The findings of this study may provide important information for water and sanitation policy makers and program managers, NGOs and government bodies involved in the implementation of water and sanitation projects to improve the service in the future. The main aim of this study was to investigate knowledge and hygienic practices of the community with respect to bacteriological quality of water from source to home.

\section{METHODS AND MATERIALS \\ Description of the Study Areas}

The present study was conducted between February and May, 2011 in three purposively selected Peasant Associations (PA) which are found in Dire-Dawa Administrative Council: The DireDawa town is located in Eastern parts of Ethiopia, which is 508 km away from Addis Ababa, capital city of Ethiopia.

All the three areas receive an average monthly rainfall of $55.71 \mathrm{~mm}$ and have bimodal pattern; the big rains occur from July to September, and the small rains from March to April. The monthly average maximum and minimum temperatures are 32.4 and $19.1^{\circ} \mathrm{C}$, respectively and the mean annual relative humidity is $48.2 \%$ (NMSA, 2010). Legedini is located $28 \mathrm{~km}$ east of Dire-Dawa City, at $09^{0} 37^{\prime \prime} 57^{\prime} .3 \mathrm{~N}$ latitude and $042^{\circ} 02^{\prime \prime} 44^{\prime} \mathrm{E}$ longitude and an altitude of 1100-1600 m.a.s.l. The area has nine villages with a total population of 4500-5000. Adada is located $18 \mathrm{~km}$ east of Dire-Dawa city. Geographically the area is located at $09^{\circ} 32^{\prime \prime} 53^{\prime} .6 \mathrm{~N}$ latitude and $41^{\circ} 56 " 23$ '.7 $\mathrm{E}$ longitude and an altitude of 1506 m.a.s.l. The area has 15 villages with a total population of 14,000 . Geographically; Legebira is located at $09^{0} 31^{\prime \prime} 23^{\prime} .4 \mathrm{~N}$ latitude and $41^{0} 57^{\prime \prime} 16^{\prime} .5 \mathrm{E}$ longitude with an altitude of 1646 m.a.s.l that is at $15 \mathrm{~km}$ east of Dire-Dawa city. The area has 6 villages with a total population of 2500-3500 (CSA, 2006; NMSA, 2010).

Farmers in this study area are engaged in croplivestock mixed agriculture and they are not food self-sufficient and most of the time they are dependent on donation from government and other donor organizations (Dawit, 2006). The major crops cultivated by the farmers are maize and sorghum. The livestock owned by the people are mainly camels, cows, donkeys, oxen, goats and sheep. 
Desalegn Amenu et al.,

The above mentioned author further reported that in each study sites some people uses water from protected sources such as springs, boreholes, deep and shallow protected well, hand-dug wells, and others use from unprotected water sources such as surface water, river, seepage, unprotected well. The common problems of the three study sites are inadequacy of clean drinking water, lack of water for agricultural and household activities and insufficient sanitary facilities. As a result, waterborne and hygiene related diseases occur frequently (Dawit, 2006).

\section{The Study Design}

A cross-sectional survey was conducted to determine the microbiological quality of water sources and to assess the households' water handling practices among the communities in the surrounding areas of Dire Dawa Town. The design also includes laboratory investigation which was carried out by collecting water samples from different sources from February, 2011 to May 2011. The questionnaires survey were done to collect data related to the respondents' socio-demographic characteristics and their water handling practices. The questionnaires were pre-tested in a few selected households living outside of the present study area.

\section{Sample Size}

The sample size for the questionnaire survey was determined based on the $5 \%$ error term and the $95 \%$ confidential interval and $P$ was taken as 0.05 . Since there were no previous related studies conducted in the area, $50 \%$ was assumed for the proportion of respondents who have good practices households $(P)$. The sample size was calculated using a formula for a single population proportion.

$$
\begin{gathered}
n=Z^{2} P(1-P) / d^{2} \\
n=Z^{2} \alpha / 2(50 \%)(1-50 \%) / d^{2}
\end{gathered}
$$

Where,

$\mathrm{n}$ = sample size

$\mathrm{P}=$ proportion of households with good water handling practices

$\mathrm{d}=$ margin of sample error

$\mathrm{Z} \alpha / 2=\mathrm{P}$ - value at $95 \% \mathrm{Cl}$ from table

\section{Questionnaire Survey on Households' Water Handling Practices}

Structured questionnaires were prepared by the investigator, which include the basic sociodemographic and the households' knowledge, awareness regarding water handling practices of households in the rural communities of the study area. The questionnaires were then administered to the selected study households at their respective residential places. A total of 384 questionnaires were administered. The questionnaires were
Sci. technol. arts Res. J., April-June 2013, 2(2): 75-82

originally developed in English and then translated to local language (Oromiffaa). The Oromiffaa version was later translated back in to English with the help of language professional. All necessary corrections were made for the actual questionnaire.

The questionnaire was pre-tested in few selected household. The pre-test was conducted near the study area which had similar characteristics to the areas where the actual study was carried out. Vague terms, phrases and questions identified during the pre-test were modified and changed. Missing responses like "no response" and "others" were added, and skipping patterns were also corrected.

\section{RESULT}

\section{Socio-demographic Characteristics}

From the three study areas, majority of the respondents were women and mostly they were Muslim. Regarding occupational status of the respondent all were farmers. Concerning their educational status majority of them were illiterates (did not able to read and write) (Table 1).

\section{Water Handling Practices Related to Collection and Transportation}

\section{Adada}

Majority of the respondents were found to collect water from tap which is about $54(43.87 \%)$, $31(24.2 \%)$ of them will collect water from the well and $43(32.78 \%)$ of them will collect water from the springs. Maximum time required to fetch water was one and half hours and minimum of thirty minutes within above $50 \mathrm{~m}$ distance. As the result indicated in this study, $90(70.3 \%)$ of the households were not aware to protect the water sources before use and $38(29.7 \%)$ of the respondents were admitted to protect the water sources before use (Table 2).

The study revealed that the most commonly preferred type of water collection container was Jerrican, which accounted $76(59.37 \%)$ followed by clay pots $52(40.63 \%)$. From the total respondents, only $48(37.5 \%)$ of the respondents will clean their containers before collection. In addition, majority of the respondents were not cover the collection container during transportation (Table 2).

As designated in this study, 28(21.88\%) of respondents were collect water once a day, 20 $(15.5 \%)$ of the respondent were collected water three times a day and the remaining $80(62.5 .9 \%)$ were collected twice a day. Daughters were highly responsible to collect water followed by mothers to fetch water from a source. Among the responsible children, majority of their age was below 10 years (Table 2). 
Table 1: Socio-demographic characteristics of respondents from Adada, Legebira \& legedini February 2011.

\begin{tabular}{|c|c|c|c|c|c|c|c|}
\hline \multirow[t]{2}{*}{ Questions items } & \multicolumn{2}{|c|}{$\begin{array}{c}\text { Adada } \\
(n=128)\end{array}$} & \multicolumn{2}{|c|}{ Legebira $(n=128)$} & \multicolumn{2}{|c|}{$\begin{array}{l}\text { Legedini } \\
(n=128)\end{array}$} & \multirow{2}{*}{$\begin{array}{l}\text { Total } \\
\text { Respondents } \\
\text { from all sites }\end{array}$} \\
\hline & No. & $\%$ & No. & $\%$ & No. & $\%$ & \\
\hline \multicolumn{8}{|l|}{ Age of the Respondents } \\
\hline $\begin{array}{l}15-24 \text { years } \\
25-34 \text { years } \\
35-44 \text { years } \\
>44 \text { years }\end{array}$ & $\begin{array}{l}22 \\
53 \\
28 \\
24\end{array}$ & $\begin{array}{c}17.4 \\
41 \\
21.9 \\
19.0\end{array}$ & $\begin{array}{l}20 \\
64 \\
28 \\
16\end{array}$ & $\begin{array}{l}15.62 \\
50 \\
21.87 \\
12.5\end{array}$ & $\begin{array}{l}20 \\
69 \\
24 \\
16\end{array}$ & $\begin{array}{c}15.62 \\
53.90 \\
18.75 \\
12.5\end{array}$ & $\begin{array}{c}62 \\
186 \\
80 \\
56\end{array}$ \\
\hline \multicolumn{8}{|l|}{ Gender } \\
\hline $\begin{array}{l}\text { Male } \\
\text { Female }\end{array}$ & $\begin{array}{c}7 \\
121\end{array}$ & $\begin{array}{c}5.5 \\
94.5\end{array}$ & $\begin{array}{c}7 \\
121\end{array}$ & $\begin{array}{c}5.5 \\
94.5\end{array}$ & $\begin{array}{c}6 \\
122\end{array}$ & $\begin{array}{c}4.68 \\
95.31\end{array}$ & $\begin{array}{c}20 \\
364\end{array}$ \\
\hline \multicolumn{8}{|l|}{ Religion } \\
\hline $\begin{array}{c}\text { Christian } \\
\text { Muslim } \\
\text { Educational Status }\end{array}$ & $\begin{array}{c}4 \\
124\end{array}$ & $\begin{array}{c}3.12 \\
96.88\end{array}$ & $\begin{array}{c}3 \\
125\end{array}$ & $\begin{array}{c}2.34 \\
97.65\end{array}$ & $\begin{array}{c}4 \\
124\end{array}$ & $\begin{array}{c}3.12 \\
96.87\end{array}$ & $\begin{array}{c}11 \\
373\end{array}$ \\
\hline $\begin{array}{c}\text { Illiterate } \\
\text { Read and write } \\
\text { Elementary } \\
\text { Secondary } \\
\text { Occupational Status }\end{array}$ & $\begin{array}{c}113 \\
13 \\
1 \\
1\end{array}$ & $\begin{array}{c}87.04 \\
10.5 \\
0.78 \\
0.78\end{array}$ & $\begin{array}{c}100 \\
23 \\
3 \\
1\end{array}$ & $\begin{array}{l}78.12 \\
17.94 \\
2.34 \\
0.78\end{array}$ & $\begin{array}{c}98 \\
10 \\
6 \\
4\end{array}$ & $\begin{array}{l}76.56 \\
7.8 \\
4.68 \\
3.12\end{array}$ & $\begin{array}{c}335 \\
33 \\
10 \\
6\end{array}$ \\
\hline $\begin{array}{c}\text { Farmers } \\
\text { Merchant } \\
\text { Government Employs } \\
\text { Housewives }\end{array}$ & $\begin{array}{c}120 \\
4 \\
2 \\
2 \\
\end{array}$ & $\begin{array}{l}93.75 \\
3.12 \\
1.56 \\
1.56 \\
\end{array}$ & $\begin{array}{c}100 \\
12 \\
8 \\
8 \\
\end{array}$ & $\begin{array}{l}78.12 \\
9.37 \\
6.25 \\
6.25 \\
\end{array}$ & $\begin{array}{c}113 \\
16 \\
0 \\
0 \\
\end{array}$ & $\begin{array}{c}88.28 \\
12.5 \\
0 \\
0 \\
\end{array}$ & $\begin{array}{c}332 \\
32 \\
10 \\
10 \\
\end{array}$ \\
\hline
\end{tabular}

Table 2: Water handling practices related to collection and transportation in rural communities of DDCAC.

\begin{tabular}{|c|c|c|c|c|c|c|c|}
\hline \multirow{2}{*}{ Questions items } & \multicolumn{2}{|c|}{$\begin{array}{c}\text { Adada } \\
(\mathrm{n}=128)\end{array}$} & \multicolumn{2}{|c|}{$\begin{array}{c}\text { Legebira } \\
(n=128)\end{array}$} & \multicolumn{2}{|c|}{$\begin{array}{c}\text { Legedini } \\
(n=128)\end{array}$} & \multirow{2}{*}{$\begin{array}{l}\text { Total from } \\
\text { all sites }\end{array}$} \\
\hline & No. & $\%$ & No. & $\%$ & No. & $\%$ & \\
\hline \multicolumn{8}{|l|}{ From where did you get water? } \\
\hline spring & 43 & 32.78 & 56 & 43.87 & 40 & 31.25 & 140 \\
\hline well & 31 & 24.2 & 41 & 32 & 68 & 53.12 & 140 \\
\hline Tap water & 54 & 43.87 & 31 & 24.2 & 20 & 15.62 & 104 \\
\hline \multicolumn{8}{|c|}{$\begin{array}{l}\text { What is the approximate distance } \\
\text { of water sources from your home? }\end{array}$} \\
\hline Below 30 min. & 20 & 15.6 & & & 10 & 7.81 & 30 \\
\hline 31-60 min. & 40 & 31.5 & 54 & 42.18 & 40 & 31.25 & 134 \\
\hline More than $60 \mathrm{~min}$. & 68 & 52.9 & 74 & 57.81 & 78 & 60.93 & 220 \\
\hline \multicolumn{8}{|c|}{$\begin{array}{l}\text { What types of container do you } \\
\text { use to collect water from sources? }\end{array}$} \\
\hline Clay pot & 52 & 40.62 & 96 & 75 & 80 & 62.5 & 156 \\
\hline \multirow{2}{*}{\multicolumn{8}{|c|}{$\begin{array}{l}\text { Do you cover the container while water } \\
\text { collection? }\end{array}$}} \\
\hline & & & & & & & \\
\hline Yes & 48 & 37.5 & 40 & 37.5 & 21 & 16.40 & 109 \\
\hline No & 80 & 62.5 & 88 & 68.75 & 107 & 83. 59 & 275 \\
\hline \multicolumn{8}{|l|}{ Do you wash your container? } \\
\hline Yes & 48 & 37.5 & 40 & 31.25 & 32 & 25 & 120 \\
\hline & 80 & 62.5 & 88 & 68.75 & 96 & 75 & 264 \\
\hline \multicolumn{8}{|c|}{$\begin{array}{l}\text { How many times do you collect water } \\
\text { per day? }\end{array}$} \\
\hline Once a day & 28 & 21.9 & 24 & 18.75 & 20 & 15.5 & 66 \\
\hline Twice a day & 80 & 62.5 & 84 & 65.62 & 80 & 65.62 & 204 \\
\hline Three times a day & 20 & 15.5 & 20 & 15.5 & 28 & 21.88 & 64 \\
\hline
\end{tabular}


Desalegn Amenu et al.,

\section{Legebira}

As the result from the Legebira site shown that, majority of the respondents were collect water from springs which accounted $56(43.87 \%), 41(32 \%)$ of them are collect water from the well and $31(24.2 \%)$ of them are collect water from the tap. The maximum time required to fetch water was more than one hour and minimum of 30 minutes. The majority of the households, 98(76.57\%) were not aware to protect the water sources before use, while only $30(23.43 \%)$ of the respondents were admitted to protect the water sources before use (Table 2 ).

The study revealed that the most commonly preferred type of water collection container was Jerrican, which is accounted about $32(25 \%)$ followed by clay pots 96 (75\%). Only 40 (31. 25\%) of the respondents cleaned their containers before collection. Majority did not cover for their collection container during transportation. Greater part of respondents, $84(65.62 \%)$ of the study subjects were found to collect water twice a day, 24 (18.75\%) of the respondent once a day and the remaining 20 $(15.5 \%)$ collect three times. Daughters were highly responsible to collect water followed by mothers to fetch water from a source. Among the responsible children, one majority of their age was below 10 years (Table 2).

\section{Legedini}

Majority of the respondents from the Legedini were compel to collect water from well (especially from unprotected one) which accounted 68 $(53.12 \%), 40(31.22 \%)$ of them are collect water from the spring and $20(15.62 \%)$ of them are collect water from the tap water. Maximum time required to fetch water was more than one hour and minimum of 30 minutes. As the result of the questionnaires pointed out that, majority of the households were not attentive to protect the water sources before use, while only $20(15.62 \%)$ of the respondents were admitted to protect the water sources before use (Table 2).

The study revealed that the most commonly preferred type of water collection container was clay pots, which is accounted about $80(62.5 \%)$ followed by Jerrican $48(37.5 \%)$. Only $21(16.40 \%$ ) of the respondents cleaned their containers before collection. Majority did not cover for their collection container during transportation (Table 6). Majority of respondents, $80(65.62 \%)$ of the study subjects were found to collect water twice a day, $20(15.5 \%)$ of the respondent once a day and the remaining $28(21.9 \%)$ collect three times a day. Daughters were highly responsible to collect water followed by mothers to fetch water from a source. Among the responsible children, one majority of their age was below 10 years (Table 2 ).
Sci. technol. arts Res. J., April-June 2013, 2(2): 75-82

\section{Water Handling Practices Related to Storage and Usage by Households}

\section{Adada}

Among the study inhabitants using separate container to store water, $8465.62 \%$ ) the households preferred clay pots and the rest $44(34.36 \%$ ) used jerrican and $68(53.12 \%)$ of them were will not wash storage containers before re-filling, similarly $70(54.65 \%)$ of households were use separate containers without cover materials. From the total selected households, $80(62.5 \%)$ of the households stored water for a day, $28(21.88 \%)$ for more than a day and $20(15.5 \%)$ for less than a day. According to the observation during the data collection, the sanitation of the area near the storage containers was poor. In addition, the storage container has a possibility of reaching animals (Table 3 ).

Pertaining to the way that the respondents' withdraw water from containers, $100(78.12 \%)$ of the respondents preferred pouring and the remaining $28(21.87 \%)$ by dipping. Among those respondent using dipping, cups without handle accounted $70(54.68 \%)$. In addition, $87(69.3 \%)$ of the respondents placing dipping or drinking utensils on the floor, the result was also consistent with the observation that was seen during data collection (Table 3). Majority of the households were not admitted to treat the water sources before collecting.

\section{Legebira}

As of the result of survey conducted at Legebira sites, along with the study population using separate container to store water, $78(54.68 \%)$ preferred clay pots and the rest of them $50(36.88 \%$ ) were used Jerrican, and $68(53.12 \%)$ of them were not wash storage containers before re-filling, similarly $88(68.75 \%)$ of the separate containers were without cover materials. Majority, $90(70.31 \%)$ of the households stored water more than a day, 24 $(18.75 \%)$ for less than a day and $14(10.93 \%)$ for more than a days (Table 7$)$. In accordance with the observation during the data collection, the sanitation of the area near the storage containers was poor. In addition the storage container has a possibility of reaching animals.

Concerning the way that the respondents' withdrew water from containers, 68(53.12\%) preferred pouring and the remaining $60(46.88 \%)$ by dipping. Among those respondent using dipping, cups without handle accounted $88(68.75 \%)$. In addition $98(76.56 \%)$ of the respondents placing dipping or drinking utensils on the floor, the result was also consistent with the observation that was seen during data collection (Table 3). All the respondents were not aware of protectingthe water sources. 
Desalegn Amenu et al.,

\section{Legedini}

At the Legedini site, among the study population using separate container to store water $90(70.31 \%)$ preferred clay pots and the rest used jerrican, and $78(62.5 \%)$ of them did not wash storage containers before re-filling, similarly $79(61.71 \%)$ of the separate containers were without handle. Greater part of the respondents, $60(46.68 \%)$ of the households stored water for more than a day, $45(35.14 \%)$ for a day and the rest were for less than a day (Table 3). According to the observation during the data collection, the sanitation area near the storage
Sci. technol. arts Res. J., April-June 2013, 2(2): 75-82

containers was poor. In addition, the storage containers have a possibility of reaching animals.

In relation to the way that the respondents' withdrew water from containers, $8(6.25)$ preferred pouring and the remaining $120(93.75 \%)$ ) by dipping. Among those respondent using dipping, cups without handle accounted $69(53.9 \%)$. In addition, 96 $(75 \%)$ of the respondents placing dipping or drinking utensils on the floor, the result was also consistent with the observation that was seen during data collection (Table 3). Predominantly, the respondents were not aware of protecting the water sources before use.

Table: 3: Water handling practices related to storage and usage by households from Adada, Legebira and Legedini in February 2011.

\begin{tabular}{|c|c|c|c|c|c|c|c|}
\hline \multirow{2}{*}{ Question items } & \multicolumn{2}{|c|}{$\begin{array}{c}\text { Adada } \\
(n=128)\end{array}$} & \multicolumn{2}{|c|}{$\begin{array}{c}\text { Legebira } \\
(n=128)\end{array}$} & \multicolumn{2}{|c|}{$\begin{array}{l}\text { Legedini } \\
(n=128)\end{array}$} & \multirow{2}{*}{$\begin{array}{c}\text { Total } \\
\text { from al } \\
\text { sites }\end{array}$} \\
\hline & No. & $\%$ & No. & $\%$ & No. & $\%$ & \\
\hline \multicolumn{8}{|c|}{$\begin{array}{l}\text { What type of storage do you use to store } \\
\text { water? }\end{array}$} \\
\hline Clay pots & 84 & 65.62 & 78 & 54.68 & 90 & 70.31 & 252 \\
\hline Jerrican & 44 & 34.36 & 50 & 36.88 & 38 & 29.68 & 122 \\
\hline \multicolumn{8}{|c|}{ Do you cover of storage container? } \\
\hline Yes & 60 & 46.88 & 60 & 46.88 & 50 & 39.06 & 170 \\
\hline No & 68 & 53.12 & 68 & 53.12 & 78 & 60.93 & 124 \\
\hline \multicolumn{8}{|c|}{ How do you collect water from the storage? } \\
\hline Pouring & 100 & 78.12 & 68 & 53.12 & 8 & 93.75 & 176 \\
\hline Dipping & 28 & 21.88 & 60 & 46.88 & 120 & 6.25 & 208 \\
\hline \multicolumn{8}{|l|}{ What the dipping juck looks like? } \\
\hline With handle & 68 & 53.12 & 40 & 31.25 & 49 & 38.28 & 157 \\
\hline Without handle & 70 & 54.68 & 88 & 68.75 & 79 & 61.71 & 227 \\
\hline \multicolumn{8}{|l|}{ Where did you put the juck? } \\
\hline On a safe place & 41 & 31 & 30 & 23.43 & 32 & 25 & 103 \\
\hline On the floor & 87 & 69 & 98 & 76.56 & 96 & 75 & 281 \\
\hline \multicolumn{8}{|c|}{$\begin{array}{l}\text { For how many days do store water in the } \\
\text { container? }\end{array}$} \\
\hline For a day & 80 & 62.5 & 14 & 10.93 & 45 & 35.14 & 108 \\
\hline More than a day & 28 & 21.88 & 90 & 70.03 & 60 & 46.68 & 208 \\
\hline Less a day & 20 & 15.5 & 24 & 18.75 & 23 & 18.18 & 68 \\
\hline \multicolumn{8}{|c|}{ Which methods of water treatment do you } \\
\hline prefer? & 6 & 4.7 & 34 & 26.6 & 46 & 32.8 & 86 \\
\hline Chemical & 7 & 5.5 & 9 & 7 & - & - & 23 \\
\hline Boiling & 3 & 2.3 & 11 & 8.6 & - & - & 14 \\
\hline Filtration & 112 & 87 & 70 & 57.8 & 79 & 67.2 & 261 \\
\hline
\end{tabular}

\section{DISCUSSION}

The results of this study indicated that springs and wells water sources were subjected for the microbiological contamination in all sites and sources. Because community unhygienic practices increase the sanitary risk of the water sources, water sources with high sanitary risk score had unacceptable water quality (unprotected well and protected well, unprotected spring and protected spring and tap water) from the three sites (Adada, Legedini and Legebira). Specially, the water sources of Legedini, unprotected well and protected well had high unhygienic practices. In contrast, the water sources of Legebira had intermediate risk of sanitary practices and the Adada water sources have less sanitary risk than the left sites. 
Desalegn Amenu et al.,

Study in Srilanka demonstrated that $(65 \%)$ to $(85 \%)$ of public water supplies mostly protected springs become microbiologically contaminated (Mertens, 1990). The higher hazard scores of water sources generally correlate with increasing magnitude of bacterial contamination (Lioud, 1992).

More than half of the respondents were doing laundry and bathing activities near the water sources. A similar study in rural Zambia and in South Wollo Ethiopia showed that poor community sanitary practices around the sources and near the catchment areas together with inadequate protection of water sources increased the sanitary risk scores of the springs and contributed to the microbiological contamination of water sources (Thomas and Cairncross, 2004; Seid et al., 2003).

In the present study, the wells and springs water sources were more contaminated than tap water. The reason behind the variation of sanitary risk scores between water sources may be due to its location and other factors (poor site selection, unhygienic practices near the water source, and inadequate treatment). Those sources having high sanitary risk score were found in a densely populated area and the number of households who practiced bathing and laundry activities are increasing near the water sources. The result of sanitary and quality monitoring in a pilot water quality surveillance study in Srilanka demonstrated water sources become contaminated because of poor site selection, protection and unhygienic management of facilities (Mertens, 1990).

From the total respondents, $66.2 \%$ of households used clay pots for household water storage while the remaining $33.8 \%$ stored water in Jerrican except in Adada, which was the majority of the respondents use Jerrican both for the collection and storage of the water. Respondents that preferred clay pots were revealed increasing of the risk of faecal coliforms than those of respondents using jerrican. This current result was harmony with the finding in Bangladesh that revealed that traditional pots increased the load of faecal coliforms (Spira et al., 1980). Similarly, Mertens (1990) and Seid et al. (2003) reported that the water stored in clay pots was shown higher proportion of load of faecal coliform than that of narrow necked container.

As indicated from the result of the survey on water handling practices, $(55.5 \%)$ of the respondents cleaned their container before transferring water from collection to storage containers and $(44.5 \%)$ of them were not cleaned the container before water collection which was much lower than a study done in Jimma town 91\% (Teklu and Kebede, 1998). Similarly, (52\%) of the
Sci. technol. arts Res. J., April-June 2013, 2(2): 75-82

respondents covered their storage container, which was almost similar with the study conducted in Garmuleta district (60\%), and Kidame Gebeya (58\%), but much lower when comparing with a study done in South wollo, 92.7\% (Seid et al., 2003). This difference may be due to inadequate and unhygienic practices related to water handling practices in the present study areas.

The main contribution for household water contaminations were unrestricted and unhygienic water collection and storage activities such as: selection household containers, lack of cover, ignorance of washing of containers before collection and transferring to storage containers, transfer of water out of storage container by dipping and placement of drinking or water drawing utensils on floor, because of this the feacal coliform load increases by two fold in household container than sources (Thomas and Cairncross, 2004).

In this study, $85.41 \%$ of the respondent dipped out water while $14.59 \%$ of the respondents poured water to collect from the storage container, which is a commendable practice. This was almost higher when comparing with studies conducted in Zambia with $80 \%$ and in south Wollo with $72 \%$ of the households was dipped out from the container (Sutton, 1989; Seid et al., 2003). The reason for these much difference is may be due to the use of narrow naked clay pots and jerrican, which is inconvenient for dipping in the study. Transfer of water out of storage containers by pouring showed statistically significant diminution on the concentration of faecal coliforms than dipping in the study area.

\section{CONCLUSIONS}

Source protection found to be necessary condition, but never be sufficient for the provision of safe water supply and in reduction of diarrheal diseases. Almost all protected springs were grossly polluted with faecal matter. The high sanitary risk score and presence of faecal coliforms in the existing water sources is attributed to constructional defects, lack of follow up, bathing and laundry activities undertaking near the source. There was a significant variation of bacteriological water quality between source water and household drinking water. Water obtained at household level is more bacteriological concentration than its origin. The main contribution for household water contaminations were unrestricted and unhygienic water collection and storage activities such as: selection household containers, lack of cover, ignorance of washing of containers before collection and transferring to storage containers, transfer of water out of storage container by dipping and placement of drinking or water drawing utensils on 


\section{Desalegn Amenu et al.,}

floor, because of this the feacal coliform load increases by two fold in household container than sources. Health education in water handling and management improve the quality of drinking water.

\section{REFERENCES}

Teferi Abegaz (2007). Assessment of Knowledge And Hygeinic Practices Towards Bacteriological Quality Of Drinking Water At Dobe Toga Kebele, Shebedino Woreda, SNNPR. M.Sc thesis.

Dawit, Ayalew. (2006). Association of Cryptosporidium Parvum, Giardia Lamblia and Entamoeba Histolytica/Dispar Infection with Drinking Water Sources among Children in Rural Part of Dire- Dawa. Addis Ababa, Ethiopia, Pp.20-30.

Lioud, B. A. (1992). Checklist of hazards: world health organization. July-august.1-7.

Mertens, T.E. (1990). Determinants of water quality, availability and use in Kurunegala Srilanka. Tropical medicine and Parasitology 41(1): 89-97.

Ministry of Health (MOH) (2007). Need Assessment to achieve Universal Access to Improved Sanitation and Hygiene, Unpublished Document, Addis Ababa, Ethiopia.
Sci. technol. arts Res. J., April-June 2013, 2(2): 75-82

NMSA(2010).

Seid Tiku, Legesse Worku and kebede Faris (2003). Factor affecting water quality from source to home in Tehuledere woreda, Northeast Ethiopia. Ethiopian Journal of Health Science 13 (2): 94-106.

Spira, W.M., Khan, Y.A. (1980). Microbiologic Surveillance of Intra-neighborhood 55 Cholera Transmission in Rural Bangladesh. Bulletin of the World Health Organization 58:731-740.

Sutton, S., Dominic. M (1989). Household water quality in rural Zambia. Water Lines 8(1): 20-21.

Teklu Mulugeta and Kebede Faris, 1998. Survey on practice of water handling and level of contamination in Jimma town. Ethiopian Journal of Health Science 8(1): 29-34.

Thomas, C and Cairncross, S. (2004). Household water management: refining the dominant paradigm. Tropical Medicine and International Health 9(2):187191.

World Health Organization (WHO) (2004). Water, sanitation and hygiene links to health, facts and figures. Geneva. 